\title{
Effects of sewage sludge application on the yield of different crops and the uptake of some heavy metals.
}

\section{ASBJØRN SORTEBERG}

\section{Department of Soil Fertility and Management, Agricultural University of Nor- way, 1432 As-NLH, Norway}

Abstract. An account is given of two pot experiments with sewage sludge.

$\mathrm{H} / 73$. Sewage sludge was added in amounts of 0,50 and $200 \mathrm{~g}$ of dry matter per pot of 5 litres $=0,20$ and 80 tons per hectare respectively, given at the start of the experiment. Two soils, a loamy sand and a clay soil, were included in the experiment which has been running for 6 years (1973-78), with oats and barley every second year. The sewage sludge was anaerobically digested and had a relatively high content of heavy metals.

Relative yields (grain + straw) for the experimental period were, as a mean of the two soil types, 100, 126 and 166 respectively for 0,50 and $200 \mathrm{~g}$ sewage sludge per pot. The uptake of $\mathrm{N}$ was 43.9 percent of added $\mathrm{N}$ in $50 \mathrm{~g}$ sludge and 32.6 percent of added $\mathrm{N}$ in $200 \mathrm{~g}$ sludge. For $\mathrm{P}$ the uptake was 23.9 and 18.5 percent respectively.

The effect of sludge on the content of heavy metals in the yields was:

Cd. Heavy effect. Heavier effect on the grain of oats than on the grain of barley.

$\mathrm{Cu}$. Distinct effect. Higher content in barley than in oats, and higher content in grain than in straw for both crops.

Ni. Heavy effect, particularly in grain of oats. Higher content in grain of oats than in straw. For barley the content was slightly higher in straw than in grain.

$\mathrm{Zn}$. Distinct effect, particularly in the first two years. Highest increase in the straw.

$\mathrm{Pb}$ and $\mathrm{Hg}$. No effect.

$14 / 71$ included rates of up to $400 \mathrm{~g}$ dry matter per pot of anaerobically digested sewage sludge, two rates of lime, with crops of oats, barley, red clover and timothy. The experiment ran for two years (1971-72). Soil: Loam.

The sludge had a positive effect on the total yield of all crops, but the highest rate had a negative effect on the grain of barley in the first year, and in the second year the hight rates caused retarded germination of all crops. The concentration of $\mathrm{Cd}, \mathrm{Cu}, \mathrm{Ni}$ and $\mathrm{Zn}$ was substantially higher in red clover than in timothy.

With the addition of roughly the same amounts of heavy metals to unlimed loamy sand $(\mathrm{H} / 73)$ and loam (14/71), oats obtained a higher concentration of $\mathrm{Cd}, \mathrm{Ni}$ and $\mathrm{Zn}$ from the sludge with the highest content of the se metals $(\mathrm{H} / 73)$.

\section{Introduction}

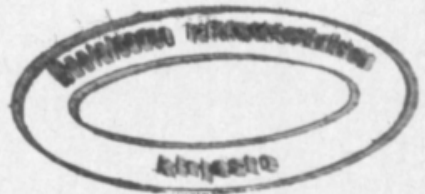

In the last decade lots of experiments have been done to study the effect of sewage sludge on the growth of plants. The effect of nitrogen and phosphorus and the effect of the organic fraction of sewage sludge are important and positive. Content 
and uptake of different heavy metals have been highly focused as an element of hazard.

In Denmark field experiments were undertaken to compare two types of sewage sludge with "low" and respectively "high" contents of heavy metals in relation to several plants as an one-time-süpply (DAMGAARD-LARSEN et al. 1979a). Sewage sludge with a "high" content of heavy metals gave a smaller crop in the supplying year than sludge with a "low" content. Different kinds of plants annually supplied with sludge in experiments carried out by the same authors (1979b), showed that the use of sewage sludge with a "low" content of heavy metals gave larger crops with higher $\mathrm{N}$-content than sludge with a "high" content of heavy metals.

KOSKELA (1978) has published results from field experiments in Finland with increasing rates of sewage sludge given to different crops grown on two soils.

In Sweden experiments have been running for a rather long time in order to find out about the positive effects of sewage sludge, e.g. in comparisons in field experiments with farmyard manure, based on the same quantity of dry matter (VALDMAA 1968), and the effect of increasing rates of sludge (VALDMAA 1970).

In Norway experiments have been made for instance by LYNGSTAD (1972), MARTINSEN (1976) and NJøS $(1978,1980)$ showing varying positive effects of sewage sludge. The last mentioned experiment carried out on levelled land, indicates that the organic fraction in sewage sludge is important under special soil conditions.

The varying content of heavy metals in sewage sludge might to a certain extent reflect the chemical contents of the plants.

Further, the uptake of heavy metals in the plants will certainly be influenced by many different conditions. The character of the soil, the content of chemically effective fractions and the $\mathrm{pH}$ will become important for the fixation and liberation of heavy metals.

It is not easy to explain the effect of sewage sludge, taking into consideration that there are several positive as well as negative individual effects contributing to the total effect. The fact that some of the heavy metals are micronutrients makes it also more complicated. Naturally, different plants may have different reactions, in regard to the size of the crop as well as in regard to the chemical content. Still, in this field a great deal remains to be done. A field experiment in Sweden may be mentioned as an example of long-running experiments. After a period of 13 years with supplying totally approx. 95 tons of dry matter in sewage sludge the content of several heavy metals in the crop was distinctly higher than on plots without sludge.

\section{Experimental}

Two pot experiments were carried out.

Experiment $H / 73$. Increasing rates of sewage sludge to oats and barley.

As part of a student's main subject at The Agricultural University of Norway a pot experiment was started in 1973 using increasing quantities of sewage sludge for oats. The experimental design included two soils, a loamy sand and a clay soil, with mixtures of these soils in four different relations. The first year results have been published (HAMAR 1974). 
In the years 1974-78 the experiment was carried on with the two soil series of loamy sand and clay soil, with barley and oats as test crops every second year.

\section{Experimental design}

Soils: Series A. Lomay sand.

Series B. Clay soil, $43 \%<0,002 \mathrm{~mm}, 50 \% 0,002-0,06 \mathrm{~mm}$.

Some other characteristics of the soils are given in Table 1 . kets):

Sewage sludge was added in 1973 . The rates are given in dry matter per pot of 5 litres (per hectare in brac-
a. Without sewage sludge
b. $50 \mathrm{~g}$ sewage sludge (20 tons)
c. $200 \mathrm{~g} " \quad$ (80 tons)

Three replicates.

The sludge was anaerobically digested sewage sludge produced by Bekkelaget Sewage Treatment Plant, Oslo, with $\mathrm{pH}=5,8$. The sludge was relatively rich in heavy metals. See Table 2 .

Every year a basic treatment including $300 \mathrm{mg} \mathrm{N}+75 \mathrm{mg} \mathrm{P}+300 \mathrm{mg} \mathrm{K}$ in soluble chemicals was added to all pots.

\section{Experiment 14/71. Increasing rates of sewage sludge to different crops.}

\section{Experimental densign}

\section{Soil: Loam}

Sewage sludge, added in 1971. The rates given in dry matter per pot of 5 litres (per hectare in brackets) were:
a. Without sew. sl.
b. $50 \mathrm{~g}$ (20 tons)
c. $100 \mathrm{~g}$ (40 tons)
d. $200 \mathrm{~g}$ ( 80 tons $)$
e. $400 \mathrm{~g}$ (160 tons)

The sludge was anaerobically digested sewage sludge produced by Bekkelaget Sewage Treatment Plant, Oslo, with $\mathrm{pH}=7,7$. Some chemical data of the sludge are given in Table 2.

Lime per pot:

Series A. Without lime ( $\mathrm{pH}$ after harvesting, 1971:ca.5.9, 1972: ca. 5.6).

Series B. $5 \mathrm{~g} \mathrm{CaO} \quad(\mathrm{pH} \quad " \quad$, 1971 "6.6, 1972: "6.2).

Crops: Oats, barley, red clover and timothy.

Three replicates.

Basic dressing with $N, P$ and $K$ to all treatments as for experiment $H / 73$.

The experiment ran for two years, 1971 and 1972.

Table 1. Exp. H/73. Some characteristics of the soils. Content of airdryed soil before addition of fertilizers and heavy metals.

\begin{tabular}{|c|c|c|c|c|c|}
\hline \multirow[t]{3}{*}{ Soil } & \multirow[t]{3}{*}{$\mathrm{pH}$} & \multicolumn{2}{|c|}{ Total } & & \multirow{2}{*}{$\begin{array}{l}\text { Available* } \\
\mathrm{mg} / 100 \mathrm{~g}\end{array}$} \\
\hline & & per cent & & & \\
\hline & & $\mathrm{N}$ & $\mathrm{Cu}$ & $\mathrm{Zn}$ & $\mathrm{P}$ \\
\hline Loamy sand $\ldots \ldots \ldots \ldots$ & 5,5 & 0,03 & 2 & 8 & 1,2 \\
\hline Clay $\ldots \ldots \ldots \ldots \ldots$ & 5,6 & 0,36 & 15 & 47 & 3,8 \\
\hline
\end{tabular}

*Al-soluble after EGNÉR et al.

Table 2. Exp. H/73 and Exp. 14/71. Content in dry matter of some elements in the sewage sludge.

\begin{tabular}{|c|c|c|c|c|c|c|c|c|c|c|}
\hline \multirow{2}{*}{\multicolumn{2}{|c|}{$\begin{array}{l}\text { Expe- } \\
\text { riment }\end{array}$}} & \multicolumn{3}{|c|}{ per cent } & \multirow[b]{2}{*}{$\mathrm{Cd}$} & \multirow[b]{2}{*}{$\mathrm{Cu}$} & \multicolumn{2}{|c|}{ ppm } & \multirow{2}{*}{$\mathrm{Pb}$} & \multirow[b]{2}{*}{$\mathrm{Zn}$} \\
\hline & & $\mathrm{N}$ & $\mathrm{NH}_{4} \mathrm{~N}$ & $\mathrm{P}$ & & & $\mathrm{Hg}$ & $\mathrm{Ni}$ & & \\
\hline $\mathrm{H} / 73$ & $\ldots \ldots$ & 3.39 & & 1.39 & 37.1 & 1976 & 11.8 & 257 & 547 & 4857 \\
\hline $14 / 71$ & $\ldots \ldots$ & 3.29 & 0.44 & 1.07 & 17.3 & 1133 & 12.9 & 193 & 546 & 2406 \\
\hline
\end{tabular}




\section{Results and Discussion}

\section{Experiment $\mathrm{H} / 73$}

Yields and content of $\mathrm{N}$ and $\mathrm{P}$

The yields in the experimental period can be seen from Figure 1. The yield increase with sewage sludge fell considerably throughout the experimental period, the highest application had, however, a clear effect even in the last two experimental years. Higher yields in Series B than in Series A without sewage sludge were levelled in the first years for oats at the highest application of sewage sludge. As to barley there was no such tendency.

The total yield (grain + straw) in grams of dry matter per pot for the 6 years was:

\begin{tabular}{rrccc}
\hline & & 0 sev.sl. & 50 g sev.sl. d.m. & 200 g sev.sl. d.m. \\
\hline Ser. A Loamy sand $\ldots \ldots \ldots \ldots \ldots$ & 170 & $257(+87)$ & $369(+199)$ \\
Ser. B Clay soil $\ldots \ldots \ldots \ldots \ldots \ldots \ldots$ & 332 & $376(+44)$ & $465(+133)$ \\
Ser.A+B Average $\ldots \ldots \ldots \ldots \ldots \ldots \ldots$ & 251 & $317(+66)$ & $417(+166)$ \\
& rel.figs. $\ldots \ldots \ldots \ldots \ldots \ldots$ & 100 & 126 & 166 \\
\hline
\end{tabular}

For sewage sludge the yield increase for both amounts was considerably higher in loamy sand than in clay soil, i.e. the effect of the sludge was highest for the soil which had the lowest content of $\mathrm{N}$ and $\mathrm{P}$ and the smallest yield without sludge. No toxicity symptoms that might have been caused by heavy metals were observed on the plants in the period of growth. Also, there was no indication that the content of copper in the sewage sludge had caused any increase in the yield in soil series A, where the copper content without sewage sludge application was low.

Increased uptake of nitrogen and phosphorus with supply of sewage sludge may be seen from Tables 3 and 4, respectively. The increased uptake is estimated as the difference between application with and without sewage sludge.

The uptakes of nitrogen and phosphorus from sewage sludge were in all somewhat higher from crops grown in loamy sand than from crops grown in clay soil. As to nitrogen this is relevant also to the same extent for the period of the residual effect $(1974-78)$ as it is for the year of application (1973). However, for phosphorus this is relevant only for the year of application. Better utilisation of the two plant nutrients in sandy soil than in clay soil might be due to a lower content in sandy soil. The exceptionally low $\mathrm{N}$-content in sandy soil may have caused a low potential of production for this soil without sewage sludge (Fig. 1). The average uptake for these

Table 3. Exp. $\mathrm{H} / 73 . \mathrm{N}$ in the crops, mg per pot, without sewage sludge and recovered in the crops by adding sludge. Figs in bracket, $\mathrm{N}$ recovered in percent.

\begin{tabular}{|c|c|c|c|c|c|c|c|c|c|}
\hline \multirow[t]{3}{*}{ Year } & \multicolumn{3}{|c|}{ Ser. A Loamy sand } & \multicolumn{3}{|c|}{ Ser. B Clay soil } & \multicolumn{3}{|c|}{ Average Ser. A+Ser. B } \\
\hline & \multirow[b]{2}{*}{0} & \multicolumn{6}{|c|}{ Sewage sludge added in 1973 , grams dry matter per pot } & \multirow[b]{2}{*}{50} & \multirow[b]{2}{*}{200} \\
\hline & & 50 & 200 & 0 & 50 & 200 & 0 & & \\
\hline & & Added & Added & & Added & Added & & Added & \\
\hline & & $1695 \mathrm{mg} \mathrm{N}$ & $6780 \mathrm{mg} \mathrm{N}$ & & $1695 \mathrm{mg} \mathrm{N}$ & $6780 \mathrm{mg} \mathrm{N}$ & & $1695 \mathrm{mg} \mathrm{N}$ & \\
\hline 1973 & 258 & $+512(30,2)$ & $+1294(19,1)$ & 484 & $+376(22,2)$ & $+1240(18,3)$ & 371 & $+444(26,2)$ & $+1267(18.7$ \\
\hline $1974-78$ & 2248 & $+426(25,1)$ & $+1235(18,2)$ & 3288 & $+176(10,4)$ & $+651(9.6)$ & 2768 & $+301(17,7)$ & $+943(13,9)$ \\
\hline $1973-78$ & 2506 & $+938(55,3)$ & $+2529(37,3)$ & 3772 & $+552(32,6)$ & $+1891(27,9)$ & 3139 & $+745(43,9)$ & $+2210(32,6$ \\
\hline
\end{tabular}


Table 4. $\mathrm{P}$ in the crops, mg per pot, without sewage sludge and recovered in the crops by adding sludge. Figs in bracket, $\mathrm{P}$ recovered in percent.

\begin{tabular}{|c|c|c|c|c|c|c|c|c|c|}
\hline \multirow[t]{3}{*}{ Year } & \multicolumn{3}{|c|}{ Ser. A Loamy sand } & \multicolumn{3}{|c|}{ Ser. B Clay soil } & \multicolumn{3}{|c|}{ Average Ser. A+Ser. B } \\
\hline & \multicolumn{9}{|c|}{ Sewage sludge added in 1973 , grams dry matter per pot } \\
\hline & 0 & 50 & 200 & 0 & 50 & 200 & 0 & 50 & 200 \\
\hline & & Added & Added & & Added & Added & & Added & Added \\
\hline & & $695 \mathrm{mg} P$ & $2780 \mathrm{mg} P$ & & $695 \mathrm{mg} \mathrm{P}$ & $2780 \mathrm{mg} P$ & & $695 \mathrm{mg} \mathrm{P}$ & $2780 \mathrm{mg}$ P \\
\hline 1973 & 28 & $+110(15,8)$ & $+366(13,2)$ & 87 & $+71(10,2)$ & $+184(6,6)$ & 58 & $+90(13,0)$ & $+275(9.9)$ \\
\hline $1974-78$ & 303 & $+78(11,2)$ & $+217 \quad(7,8)$ & 599 & $+74(10,7)$ & $+261(9,4)$ & 452 & $+76(10,9)$ & $+239(8,6)$ \\
\hline $1973-78$ & 331 & $+188(27,0)$ & $+583(21,0)$ & 686 & $+145(20,9)$ & $+445(16,0)$ & 510 & $+166(23.9)$ & $+514(18,5)$ \\
\hline
\end{tabular}

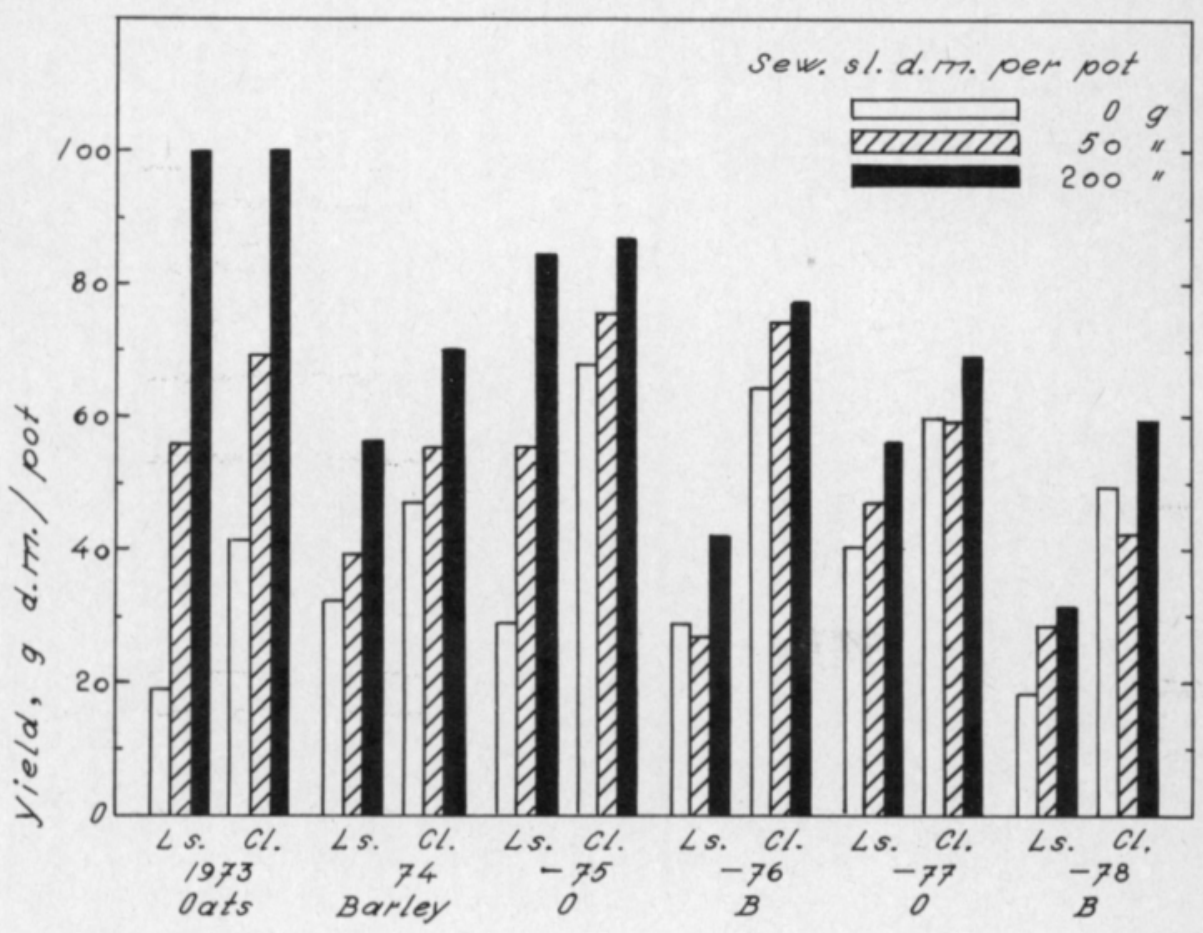

Fig. 1. Yields, dry matter, sum grain + straw. Ls. = Loamy sand. Cl. $=$ Clay soi.

two soils was in the first year approx. 26 percent for $\mathrm{N}$ and 13 percent for $\mathrm{P}$, respectively, from the smallest amounts of sewage sludge. For the whole experimental period the uptake was about 44 percent for $\mathrm{N}$ and 24 percent for $\mathrm{P}$, respectively. This utilization of plant nutrients is roughly the same as the one caused by the application of the same amount of dry matter in farmyard manure. The highest amount of sewage sludge caused a somewhat lower utilization for both nutrients. The uptake of the two nutrients in the last years of the experimental period indicates in addition that the residual effect will still be going on for some time for both sludge quantities.

DAMGAARD-LARSEN et al. (1979b) added over a three-year period every year sewage sludge low in heavy metals to different crops grown in different soil localities. As a mean for crops and soil types the utilization of nitrogen was 14 percent of nitrogen added by slugde. The utilization of nitrogen in this actual pot experiment 
was for the first year 18.7 percent as an average of the two soil types with the highest rate of sludge (Table 3 ). Better utilization of $\mathrm{N}$ from sewage sludge in the pot experiment than in DAMGAARD-LARSENS field experiments is probably due to more favourable conditions for crop production in the pot experiment, and about 30 percent lower addition of nitrogen in the pot experiment than in the field experiments. Further, the content of $\mathrm{NH}_{4}-\mathrm{N}$ in the applied sludge in the experiments, may have differed.

Heavy metals in the crops

The contents of cadmium, copper, nickel, zinc, lead and mercury in grain and straw were determined separately each year. For the four first mentioned metals the concentration obviously increased, even with the lowest application of sewage sludge, which naturally must be seen in relation to the hight concentration of heavy metals in the sludge.

For cadmium, copper, nickel and zinc the concentration is presented in Figures $2-5$ as an average for the two soil series.

The content of cadmium increased substantially with application of sewage sludge, particularly in oats in the first year (Fig. 2). The content increased with increasing rates of sewage sludge in grain as well as in straw, even for the last two experimental years. Throughout the period the increase was far higher in grain of oats than in grain of barley, but also for grain of barley there was some increase with the lowest application of sewage sludge, and the concentration of cadmium was at least tripled for the highest one.

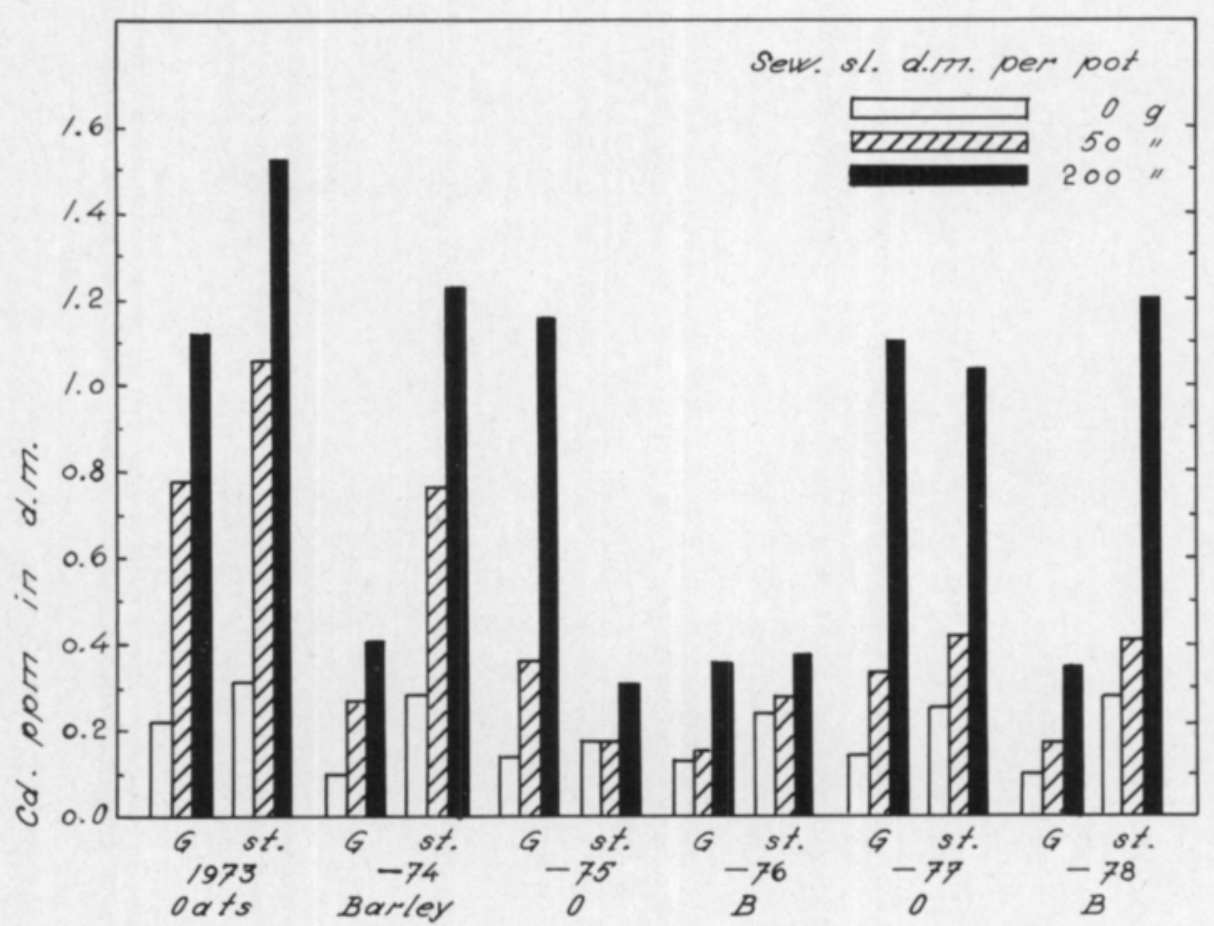

Fig. 2. Cadmium concentration in grops, grain $(G)$ and straw (St.). Mean loamy sand and clay soil. 
Cadmium may be one of the heavy metals that most requires attention when using sewage sludge in plant growing.

The content of copper increased with the application of sewage sludge every year (Fig. 3). The content is considerably higher in barley than in oats in grain as well as in straw. For both crops the content is much higher in grain than in straw at all rates of sewage sludge. The content decreased throughout the experimental period, with as well as without sewage sludge. Therefore, it is not definite whether the ability of the sewage sludge to supply copper had decreased throughout the experimental period.

DUDAS and PAWLUK (1977) found significantly higher contents of copper in grain of barley than in grain of oats grown in the Gray Soil Zone in Alberta. Also for straw the copper content was higher, and partly significantly higher in barley than in oats.

Since copper is essential not only for higher plants, but also in the diet for humans and domestic animals, it is a matter of importance that the content in plants is high enough. The importance of this is certainly not the same as it was a few decades ago, yet it is also of current interest. The copper content of grain of barley in 1974, after the highest application of sewage sludge, was substantially higher than the content (10 ppm) which in England is required (ANON. 1965) as a minimum concentration for cattle (ref. MILTIMORE et al. 1970). Generally, the importance of "high" or "low" content of an essential element in a single crop depends greatly on the composition of the diet as a whole. In case a relatively high copper content is not

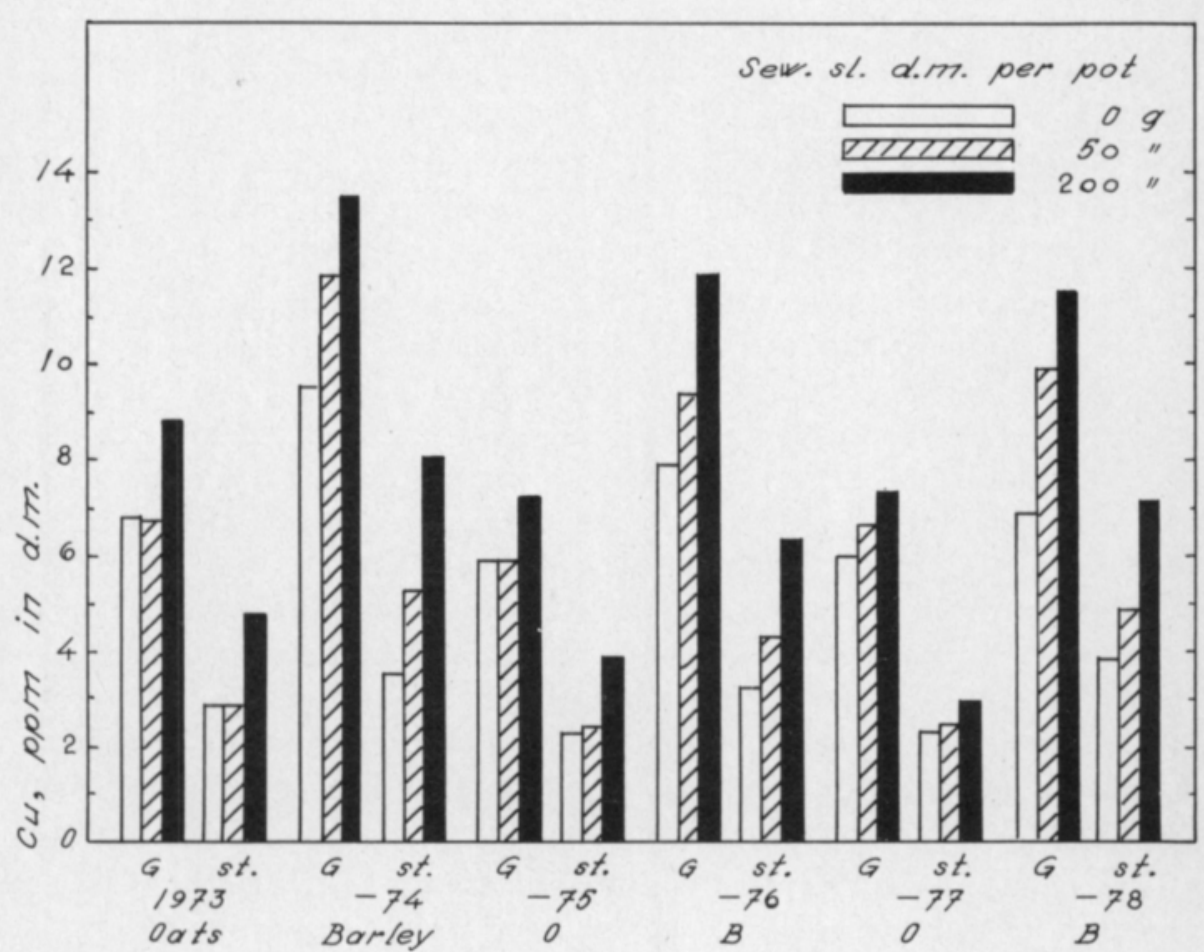

Fig. 3. Copper concentration in crops, grain $(\mathrm{G})$ and straw (St.). Mean loamy sand and clay soil. 
required, e.g. as feed for sheep, the experiment indicates that one should be careful with heavy applications of sewage sludge.

It should be stressed that the copper content in the grain of oats is not higher after the heaviest application of sewage sludge than without sewage sludge in the grain of barley.

The content of nickel increases considerably with application of sewage sludge (Fig. 4). In comparison with barley the content in oats was generally many times as high. The difference is particularly hight for grain, in any case the content in grain of oats is many times higher compared with the content in straw, especially with sludge application. This bears out the experiments made previously by HUNTER and VERGNANO (1952), HALSTEAD et al. (1969), ANDERSSON and NILSSON (1975) and by SORTEBERG $(1974,1978)$, who found a higher content of nickel in grain than in straw of oats. For barley there is a tendency to a higher nickel content in straw than in grain, particularly in treatments without sewage sludge. Furthermore, there is a falling content of nickel throughout the experimental period both for oats and barley, particularly after application of sludge.

The distinct difference between grain of barley and oats as to nickel content indicates that the choice of oats or barley as crop can be important when a reduction of the nickel content is required.

The content of zinc increases every year with application of sewage sludge (Fig. 5). The increase is distinct the first two years, but it is also evident for the rest of the experimental period. With the substantial increase in the first two years with heavy application of sewage sludge, the content is much higher in straw than in grain. For the rest of the period the zinc content has been rather moderate, and after heavy application highest partly in grain, partly in straw. Without sewage sludge the zinc content falls slightly in the course of the experiment. Except for the first year in oats, the content is higher in grain than in straw in all years without application of sludge for both oats and barley. In grain the content was slightly higher in oats than in barley. This is not in accordance with analyses of the same crops grown in the Gray Soil Zone in Alberta (DUDAS and PAWLUK 1977), where a significantly higher content of zinc was found in grain of barley than in grain of oats.

The content of zinc in straw of oats in the first year after heavy application of sewage sludge is very high and about 50 percent higher than declared e.g. by JONES (1972) as a toxic concentration in mature leaves (400 ppm in d.m.). BOAWN and RASMUSSEN (1971) applied increasing rates of soluble zinc to different crop species grown in alkaline soil. Cereal crop species accumulated higher concentrations of zinc and had greater reductions in growth than did legumes. At concentrations of $400-$ $560 \mathrm{ppm} \mathrm{Zn}$ in d.m. the yield reductions of the cereals were distinct. In the remaining years the content has, however, been far beyond this threshold. As a micronutrient and an essential element for human food and feed for domestic animals, zinc is also interesting in relation to the required content in plants. MILTIMORE et al. (1970) indicates a content of $50 \mathrm{ppm}$ as the required minimum for cattle feed. The content of both oats and barley is partly much lower without sewage sludge in the remaining part of the period than the required content.

The content of lead varied a lot from year to year and has been independent of the application of sewage sludge. Neither has there been any trend in the lead concentration in the experimental period caused by the sludge. There was no distinct 


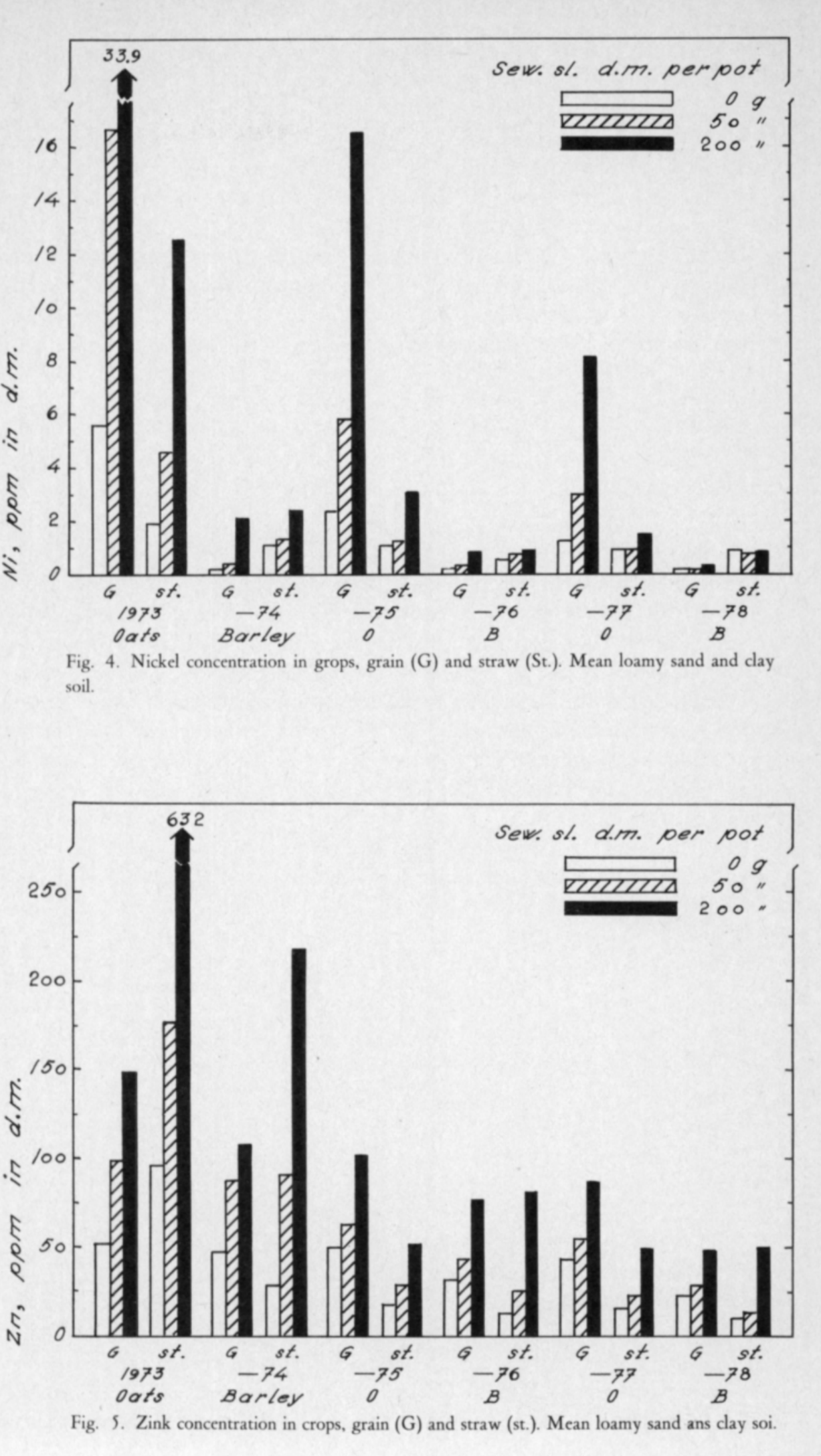


difference in the content of oats and barley. For oats as well as barley the lead content was substantially higher in straw than in grain in all years. As a mean of 36 observations (years $\times$ rates of sewage sludge $X$ soils) the lead content in dry matter in grain was $0.65 \mathrm{ppm}$ and in straw 2.05 .

No effect or only a moderate effect on the lead content by adding sewage sludge has been observed in many investigations, among other by HINESLY et al. (1972), by KING et al. (1974) and by ZWARICH and MILLS (1979). SORTEBERG $(1974,1978)$ found substantially smaller increases in oats of lead content than of cadmium, cobalt and nickel contents when adding an equivalent amount of the respective metal in soluble from as $\mathrm{MeIICl}_{2}$.

The content of mercury was not influenced by the application of sewage sludge. In grain the content usually was $<0.01 \mathrm{ppm}$ in d.m., and in straw the content generally was within the figures $0.02-0.05 \mathrm{ppm}$.

\section{Experiment $14 / 71$}

Crop yields

The yields of different crops for 1971 are presented in Tables 5 and 6. The highest rate of sewage sludge has doubled or tripled the yield of red clover and of timothy (Table 6). For barley, without lime, the yield increase has stopped already at the lowest rate of sludge. The highest rate has increased the total yield (grain + straw) only slightly compared with no sludge, and the yield of grain dropped to only half the weight. Also with lime the grain yield of barley was reduced by the highest rate of sludge. The total yield of oats has increased 50-70 percent with the highest rate of sludge, but without lime the yield of grain is highest for lower rates of sewage sludge.

The experiment continued in 1972, but the crops were not analysed. No crops continued to grow in the same soil. The following arrangement for crop rotation was made:

$\begin{array}{llll}\text { 1971. Series of Oats } & \text { Barley } & \text { Red clover } & \text { Timothy } \\ \text { 1972. } " \text { " Red clover } & \text { Timothy } & \text { Oats } & \text { Barley }\end{array}$

The emergence was retarded and uneven in all series by the two highest rates of sludge. Nevertheless there was a yield increase with increasing rates of sludge for all crops, also for grain of oats and barley (Table 7).

The positive effect of the sludge application on the crop yield may mainly depend on the content of nitrogen and phosphorus and to a less extent on the content of potassium. The clay soil used in this experiment should not be short of trace elements, magnesium or sulphur. The reason for the yield decrease in grain, particularly in barley in 1971, and the retarded germination of all crops in 1972 after high rates of sewage sludge, is unknown, but some relations may be mentioned:

With the highest rate of sewage sludge the supplying of $\mathrm{N}, \mathrm{P}$ and $\mathrm{K}$ should be calculated at $704 \mathrm{~kg} \mathrm{NH}_{4}-\mathrm{N}, 1712 \mathrm{~kg} \mathrm{P}$ and $469 \mathrm{~kg} \mathrm{~K}$ per hectare (2 mill. litre soil). With the two highest rates of sludge these nutrients were supplied in amounts embodying a certain risk. As a matter of fact, the negative effect of the high rates of sewage sludge was of a different kind in the two years. The explanation may be that 
the negative effects have been caused by different factors depending on the decomposition of the organic matter in the sewage sludge.

The supply of chlorine with the highest rate of sewage sludge was $141 \mathrm{~kg}$ per hectare, which amount should not be dangerous to the crops grown in this experiment.

Heavy metals in the crops

The heavy metals $\mathrm{Cd}, \mathrm{Ni}$ and $\mathrm{Zn}$ may not have constituted a risk for oats and barley, compared to the content of these metals in exp. H/73. Roughly, the content of $\mathrm{Ni}$ and $\mathrm{Zn}$ in oats and barley was of about the same size in exp. $\mathrm{H} / 73$ with the hea-

Table 5. Exp. 14/71. Yields and concentration of heavy metals in oats and barley 1971 by different rates of sewage sludge.

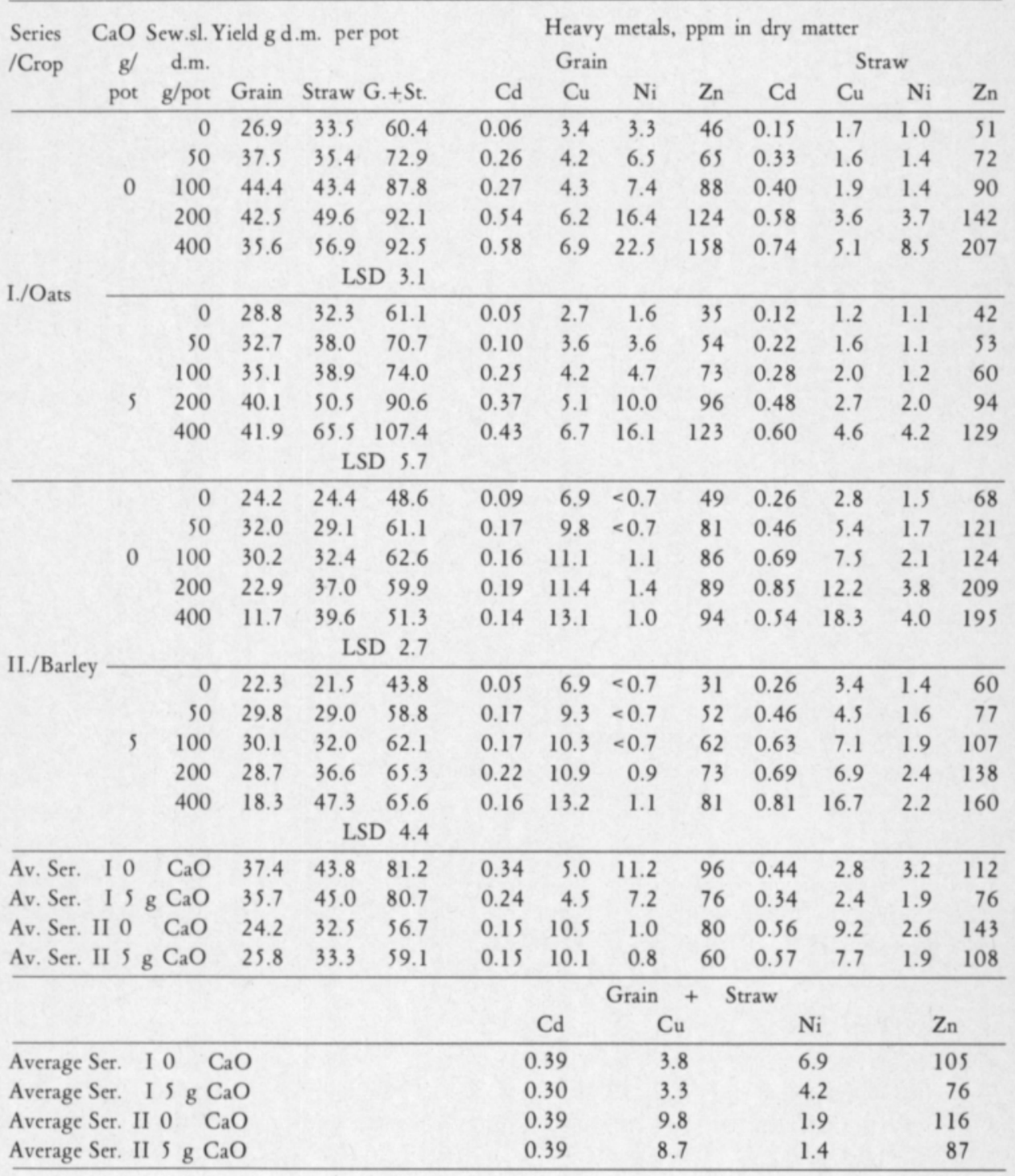


viest rate of sludge when no negative effect was observed, and the content of $\mathrm{Cd}$ was rather higher in exp. $\mathrm{H} / 73$, in both oats and barley, also grown in clay soil. The concentration of $\mathrm{Cu}$ was particularly high in the straw of barley with the highest rate of sludge in exp. 14/71, which indicates that the transfer of $\mathrm{Cu}$ from the vegetative part to the generative part of the plant had been disturbed. Interaction between heavy metals may have occurred. Thus, CHUMBLEY (1971) assumed that $\mathrm{Cu}$ is twice as toxic and $\mathrm{Ni}$ eight times as toxic as $\mathrm{Zn}$ (Ref. MACLEAN et al. 1978).

The higher concentration of $\mathrm{Ni}$ in grain than in straw, the higher content of $\mathrm{Cu}$ in barley than in oats and the higher content of $\mathrm{Cu}$ in grain than in straw of oats and for barley up to moderate rates of sludge, are well in agreement with the results in exp. $\mathrm{H} / 73$. As mentioned already, the concentration of $\mathrm{Cu}$ was exceptionally high in straw of barley at high application of sewage sludge.

The content of all heavy metals analysed was usually distinctly higher in red clover as compared to timothy. Lime reduced the content of $\mathrm{Ni}$ and $\mathrm{Zn}$ in both crops and of $\mathrm{Cd}$ in red clover. The content of $\mathrm{Cu}$ in red clover showed a tendency to increase with liming.

Table 6. Exp. 14/71. Yields and concentration of heavy metals in red clover and timothy 1971, by different rates of sewage sludge.

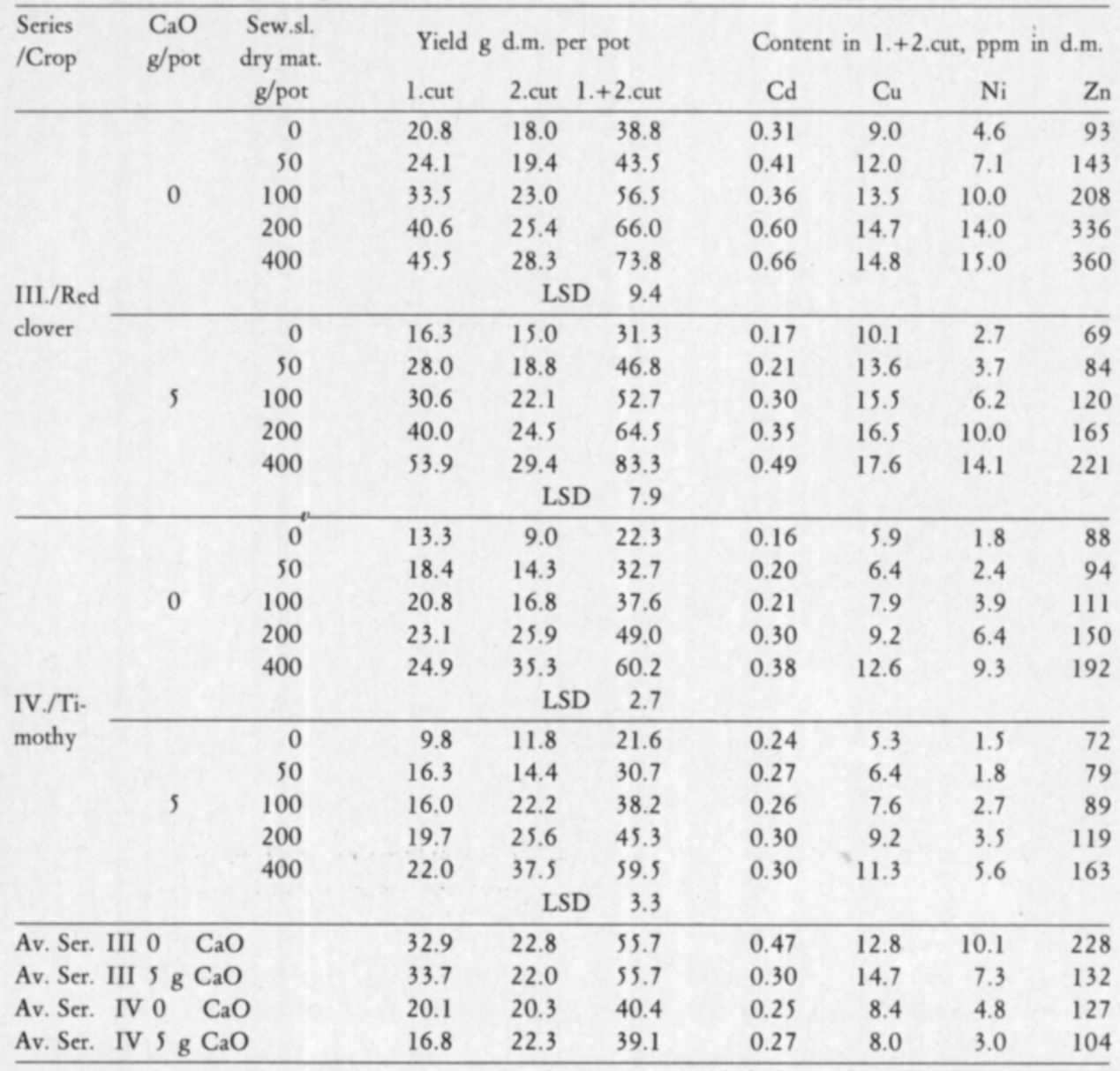


Table 7. Exp. 14/71. Yields 1972, $g$ airdried matter per pot.

\begin{tabular}{|c|c|c|c|c|c|c|c|c|c|c|c|}
\hline \multicolumn{2}{|c|}{$\mathrm{g}$ per pot of } & \multirow{2}{*}{\multicolumn{2}{|c|}{$\begin{array}{r}\text { Ser. I } \\
\text { Red cl. } \\
\text { Sum two } \\
\text { cuts }\end{array}$}} & \multirow{2}{*}{\multicolumn{2}{|c|}{$\begin{array}{r}\text { Ser. II } \\
\text { Timothy } \\
\text { Sum two } \\
\text { cuts }\end{array}$}} & \multicolumn{3}{|c|}{$\begin{array}{c}\text { Ser. III } \\
\text { Oats }\end{array}$} & \multicolumn{3}{|c|}{$\begin{array}{l}\text { Ser. IV } \\
\text { Barley }\end{array}$} \\
\hline \multirow[t]{2}{*}{$\mathrm{CaO}$} & $\begin{array}{l}\text { Sew.sl. } \\
\text { dry matter }\end{array}$ & & & & & \multicolumn{2}{|c|}{ G. +straw } & Grain & \multicolumn{2}{|c|}{ Gr. +straw } & Grain \\
\hline & 0 & & 44.5 & & 31.7 & & 72.5 & 33.2 & & 35.6 & 16.4 \\
\hline \multirow[t]{6}{*}{0} & 50 & & 48.4 & & 35.1 & & 86.1 & 41.9 & & 56.0 & 26.8 \\
\hline & 100 & & 50.7 & & 36.7 & & 87.9 & 41.5 & & 66.3 & 32.1 \\
\hline & 200 & & 55.0 & & 43.0 & & 07 & 52.6 & & 81.9 & 39.0 \\
\hline & 400 & & 60.1 & & 53.5 & & 24 & 63.0 & & 105 & 53.8 \\
\hline & & LSD & 1.9 & LSD & 1.7 & LSD & 3.7 & 1) & LSD & 6.7 & 1) \\
\hline & 0 & & 45.5 & & 28.5 & & 75.0 & 36.1 & & 31.2 & 10.9 \\
\hline \multirow[t]{5}{*}{5} & 50 & & $\$ 1.2$ & & 33.7 & & 90.4 & 43.9 & & 60.7 & 29.9 \\
\hline & 100 & & 41.9 & & 34.0 & & 93.2 & 46.6 & & 66.1 & 32.7 \\
\hline & 200 & & 51.4 & & 41.2 & & 112 & 55.0 & & 84.3 & 42.3 \\
\hline & 400 & & 55.9 & & 59.8 & & 27 & 64.1 & & 106 & 52.4 \\
\hline & & LSD & 3.5 & LSD & 2.1 & LSD & 4.7 & リ & LSD & 3.5 & リ \\
\hline \multicolumn{2}{|c|}{ Av. without $\mathrm{CaO}$} & & 51.7 & & 40.0 & & 95.5 & 46.6 & & 69.0 & 33.6 \\
\hline \multicolumn{2}{|c|}{ Av. with $\mathrm{CaO}$} & & 49.2 & & 39.4 & & 99.5 & 49.1 & & 69.7 & 33.6 \\
\hline
\end{tabular}

1) Grain alone was not statistically tested.

Table 8. Amounts of heavy metals added by sewage sludge, and concentration in dry matter in oats (grain + straw) the first experimental year.

\begin{tabular}{|c|c|c|c|c|c|c|c|}
\hline & Experiment & $\mathrm{H} / 73^{1}$ & $14 / 71^{2}$ & $\mathrm{H} / 73^{1}$ & $14 / 71^{2}$ & $\mathrm{H} / 73^{1}$ & $14 / 71^{2}$ \\
\hline Metal & Sew, sludge g d.m./pot & 0 & 0 & 50 & 100 & 200 & 400 \\
\hline \multirow{2}{*}{$\mathrm{Cd}$} & Metal in sev. sl. mg/pot & 0 & 0 & 1.85 & 1.73 & 7.4 & 6.9 \\
\hline & Metal in oats $\mathrm{ppm}$ & 0.36 & 0.11 & 1.20 & 0.33 & 1.71 & 0.68 \\
\hline \multirow{2}{*}{$\mathrm{Cu}$} & Metal in sev. sl. mg/pot & 0 & 0 & 98.8 & 113 & 395 & 453 \\
\hline & Metal in oats ppm & 4.2 & 2.5 & 4.8 & 3.1 & 8.8 & 5.8 \\
\hline \multirow{2}{*}{$\mathrm{Ni}$} & Metal in sew. sl. mg/pot & 0 & 0 & 12.9 & 19.3 & 51.4 & 77.2 \\
\hline & Metal in oats ppm & 3.7 & 2.0 & 13.3 & 4.4 & 32.1 & 13.9 \\
\hline \multirow{2}{*}{$Z_{n}^{n}$} & Metal in sew. sl. mg/pot & 0 & 0 & 243 & 241 & 971 & 962 \\
\hline & Metal in oats ppm & 61 & 49 & 148 & 89 & 435 & 188 \\
\hline
\end{tabular}

1 Loamy sand, $\mathrm{pH} 5,7-5.8$

2 Loam, unlimed, pH 5. 7-6. 0

A comparison between the content of heavy metals in oats grown as the first crop in loamy sand (exp. H/73) and in unlimed loam (exp. 14/71) showed a far higher content of $\mathrm{Cd}, \mathrm{Ni}$ and $\mathrm{Zn}$ in exp. H/73 than in exp. 14/71, particularly with the addition of sewage sludge that supplied the soils with roughly the same amounts of metal (Table 8). The difference in metal concentration in crops may depend on the soils, but as the two soils had about the same $\mathrm{pH}$ levels, the different concentrations of metals indicate that the sewage sludge with the highest content of heavy metals (exp. H/73) has effected a more rapid mobilizing of some heavy metals in relation to the total supply than has the sludge with a lower metal concentration. 


\section{References}

ANDERSSON, A. \& NILSSON, K. O. 1975. Effekter på tungmetallhalterna i mark och växt vid tillförsel av rötslam som växtnäringskälla och jordförbättringsmedel. Rapp. 96. Avd. växtnäringslära. Lantbr.högsk. Uppsala.

ANON. 1965. The nutrient requirements of farm livestock. Agricultural Research Council. No. 2. Ruminants. 264 p. London.

BOAWN, C. \& RASMUSSEN, P. E. 1971. Crop response to excessive zink fertilization of alkaline soil. Agron. Journ. 63, Nov.-Des. 874-876.

CHUMBLEY, C. G. 1971. Permissible levels of toxic metals in sewage used on agricultural land. A.D.A.S. Advisory Paper No. 10. Ministry of Agriculture, Fisheries and Food.

DAMGAARD-LARSEN, S., SØNDERGAARD-KLAUSEN, P. \& LARSEN, K. E. 1979a. Engangstilf $\phi r-$ sel af slam fra rensningsanlag til landbrugsjord. Tidsskr. Pl. avl 83:387-403.

- , SØNDERGAARD-KLAUSEN, P. \& LARSEN, K. E. 1979b. Årlig tilførsel af slam fra rensningsanlæg til landbrugsjord. Tidsskr. Pl. avl. 83: 349-386.

DUDAS, M. J. \& PAWLUK, S. 1977. Heavy metals in cultivated soils and in cereal crops in Alberta. Can. J. Sci. 57: 329-339.

HALSTEAD, R. L., FINN, B. J. \& MACLEAN, A. J. 1969. Extractability of nickel added to soils and its concentration in plants. Can. J. Soil Sci. 49: 335-342.

HAMAR, T. O. 1974. Kloakkslam til plantedyrking. Litteraturstudier og resultater av egne karfors $\phi k$ med kloakkslam til ulike vekster og jordtyper. Inst. jordkultur. NLH 127.

HINESLY, T. D., Jones, R. L. \& ZIEGLER, E. L. 1972. Effects on corn by applications of heated anaerobically digested sludge. Compost Sci. 13: 26-30.

HUNTER, J. G. \& VERGNANO, O. 1952. Nickel toxicity in plants. Ann. Appl. Biol. 39: 279-284.

JONES, J. B. Jr. 1972. Plant tissue analysis for micronutrients p. 317-346. Micronutrients in agriculture. Edit. by MORTVEDT, J. J., GIORDANO, P. M. \& LINDSAY, W. L. Soil Sci. Amer. Madison, Wisconsin, USA.

KING, L. D., RUDGERS, L. A. \& WEBBER, L. R. 1974. Applications of municipal refuse and liquid sewage sludge to agricultural land: 1. Field study. J. Environ. Qual. 3: 361-366.

KOSKELA, I. 1978. Disposal of municipal sludges containing heavy metals in agricultura. Seminar on Heavy Metals. Copenhagen 1978. Doc. 3,5: 1-10.

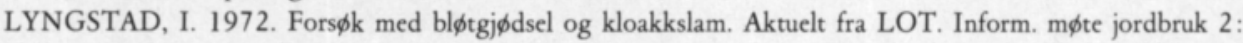
$16-20$.

MACLEAN, A. J. \& DEKKER, A. J. 1978. Availability of zink, copper and nickel to plants grown in sewagetreated soils. Can. J. Soil Sci. 58: 381-389.

MARTINSEN, J. 1976. Bruk av septiktankslam og råslam ved dyrking av korn. PRA 3. 3. Slam og kompost på jord og vegetasjon, 54 .

MILTIMORE, J. E., MASON, J. L. \& ASHBY, D. L. 1970. Copper, zink, manganese and iron variation in five feeds for ruminants. Can. J. Anim. Sci. 50: 293-300.

NJØS, A. 1978. Behov for jordforbedring. Kloakkslam. Behandling og bruk. H $\phi$ gskoledagene ved NLH. 1978: 82-89.

- 1980. Jordforbedring og jordarbeiding. Aktuelt fra LOT. No. S.

SORTEBERG, A. 1974. The effect of some heavy metals on oats in a pot experiment with three different soil types. J. Scient. Agric. Finl. 46: 277-288.

- 1978. Effects of some heavy metals on oats in pot experiments with three different soil types. J. Scient. Agric. Finl. 50: 317-334.

VALDMAA, K. 1968. Preliminära data från försök med blötgödsel och rötslam. Rapp. 3. Avd. växtnäringslära. Lantbr.högsk. Uppsala.

- 1970. Sammansättning och försök med rötslam. Rapp. 30. Avd. växtnäringslära. Lantbr.högsk. Uppsala.

ZWARICH, M. A. \& MILLS, J. G. 1979. Effects of sewage sludge application on the heavy metal content of wheat and forage crops. Can. J. Soil Sci. 59: 231-239.

Ms received October 14, 1980. 


\title{
Maahan lisätyn asumajätevesilietteen vaikutus kasvien satoon ja raskasmetallipi- toisuuteen
}

\section{Asbjфrn Sorteberg}

\author{
Norjan Maatalousyliopisto, 1432 As-NLHm Norja
}

Oslon jätevedenpuhdistamon anaerobisesti mädätettyä lietettä, joka sisältää suhteellisen runsaasti raskasmetalleja, lisättiin astiakoemaihin ja tutkittiin lietelisäyksen vaikutusta eri kasvien satoihin ja raskasmetallipitoisuuksiin. Koemaina oli hieta ja savi. Verrattavat lietemäärät kokeessa 1, joka keski 6 vuotta, olivat 0,50 ja $200 \mathrm{~g}$ lietteen kuiva-ainetta 5 maalitraa kohden eli 0,20 ja 80 tonnia hehtaarille. Lietelisäys tehtiin vain kerran kokeen alkaessa. Joka toinen vuosi kasvatettiin kauraa, joka toinen vuosi ohraa.

Pienempi lietemäärä lisäsi 6 vuoden yhteenlaskettua jyvä- ja olkisatoa keskimäärin $26 \%$, suurempi lietemäärä $66 \%$. Kasvit ottivat 6 vuoden aikana yhteensä pienemmän lietemäärän typestä 43,9\% ja suuremman lietemäärän typestã $32,6 \%$. Lietteen fosforin otto oli vastaavasti 23,9 ja $18,5 \%$.

Kasvien kadmiumpitoisuutta lietelisäys kohotti hyvin voimakkaasti. Vaikutus oli suurempi kauran kuin ohran jyviin. Myös kuparipitoisuus nousi selvãsti lietelisãyksen seurauksena. Ohran kuparipitoisuus kohosi enemmān kuin kauran, ja kummallakin viljalla jyvien pitoisuus nousi enemmān kuin olkien. Nikkelipitoisuutta liete kohotti voimakkaasti. Kauran jyvien $\mathrm{Ni}$-pitoisuudet kohosivat eniten. Ohralla sen sijaan olkien Ni-pitoisuus kohosi enemmän kuin jyvien. Sinkkipitoisuudet kohosivat etenkin kahtena ensimmäisenä vuotena. Vaikutus näkyi parhaiten olkisadoissa. Viljojen lyijy- ja elohopeapitoisuuksiin lietelisäys ei vaikuttanut.

Toisessa kaksivuotisessa astiakoesarjassa tutkittiin hiuemaahan lisätyn asumajätevesilietteen vaikutusta kauraan, ohraan, puna-apilaan ja timoteihin. Suurin lietelisäys oli $400 \mathrm{~g}$ kuiva-ainetta 5 litraan maata vastaten 160 tonnia/ha. Myös kalkitus oli koetekijänä.

Liete lisäsi kaikkien kasvien kokonaissatoja, mutta suurin lietemäärä vaikutti kuitenkin haitallisesti ohran ensimmäisen vuoden satoon ja hidasti kaikkien kasvien itämistä toisena vuonna. Kadmium-, kupari-, nikkeli- ja sinkkipitoisuudet olivat selvästi korkeampia puna-apilalla kuin timoteilla. Kalkitus alensi molempien kasvien nikkeli- ja sinkkipitoisuuksia ja puna-apilalla myös kadmiumpitoisuutta. Sen sijaan puna-apilan kuparipitoisuutta kalkitus pyrki lisäämään.

Kokeessa verrattiin lietettä, jonka raskasmetallipitoisuus oli suhteellisen korkea, sellaiseen lietteeseen, jonka raskasmetallipitoisuudet olivat huomattavasti alhaisempia. Jälkimmäistä käytettiin niin paljon runsaammin, että maahan lisätyt raskasmetallien kokonaismäärät tulivat likimain samoiksi. Ensiksi mainittu, runsaasti raskasmetalleja sisältävä liete kohotti kauran kadmium-, nikkeli- ja sinkkipitoisuuksia selvästi enemmän.

\footnotetext{
Selostuksen laatinut P. Elonen
} 